\title{
The ruin of the Roman Temple of Kedesh, Israel; example of a precariously balanced archaeological structure used as a seismoscope
}

\author{
Gregor Schweppe ${ }^{1, *}$, Klaus-G. Hinzen ${ }^{1}$, Sharon K. Reamer ${ }^{1}$, Moshe Fischer $^{2}$, Shmuel Marco $^{3}$ \\ ${ }^{1}$ Earthquakegeology and Archaeoseismology Group, Institute of Geology and Mineralogy, Cologne University, Bergisch \\ Gladbach, Germany \\ 2 Department of Archaeology and Institute of Archaeology, Tel Aviv University, Israel \\ 3 School of Geosciences, Tel Aviv University, Tel Aviv, Israel
}

\author{
Article history \\ Received September 14, 2016; accepted May 25, 2017. \\ Subject classification: \\ Archaeoseismology, Collapsed wall, Back calculation of ground motion, Precariously balanced archaeological structure.
}

Link for Electronical Supplement: http://www.seismo.uni-koeln.de/esupp/AoG/S/index.htm

\section{ABSTRACT}

In certain regions and under favorable geologic conditions, precariously balanced rocks may form. These types of unusual formations have been used to estimate yield ground motions. Because such balanced rocks have not been 'unbalanced', they can be used as a rough estimate for ground motions which have not been reached or exceeded since the balanced formation achieved its contemporary state. We hypothesize that other ancient manmade structures, delicate in terms of stability and particularly those that have survived earthquake ground motions intact, can be used in the same manner. We therefore suggest that these structures act as local seismoscopes which might be capable of determining maximum upper ground motion bounds. We apply the concept of the study of precariously balanced rocks to the ruin of the Roman Temple of Kedesh, located in close proximity to a branch of the Dead Sea Transform Fault. The delicate-looking ruin was surveyed with a 3D laser scanner. Based on the point cloud from that survey, a discrete element model of the remaining temple wall was constructed. To test the stability of the model we used 54 analytical ground motion signals with frequencies ranging from 0.3 to $2 \mathrm{~Hz}$ and $P G A s$ between 1 and $9 \mathrm{~m} / \mathrm{s}^{2}$. These calculations reveal two failure mechanisms. Additionally, ground motions of eight earthquakes, including two assumed local earthquake scenarios, five historical earthquakes of the region and one strong motion record of the 1999 Taiwan Chi Chi earthquake have been used to test the hypothesis. None of the simulated earthquakes (assumed or historically documented) toppled the ruin; only the strong motion record collapsed the structure. The simulations reveal a surprisingly high stability of the ruin of the Roman Temple of Kedesh mainly due to the small height to width ratio of the remaining walls. However, ground motion with large PGAs at a low frequency range in EW direction does collapse the remains of the temple.
\end{abstract}

\section{Introduction}

Following the definition by C.F Richter [1958], a seismoscope is a device which indicates the occurrence of an earthquake but does not write a record. In the second half of the $19^{\text {th }}$ and early $20^{\text {th }}$ century a wide variety of such instruments were designed; some were even still in use in the middle of the $20^{\text {th }}$ century [Hinzen and Kovalev 2010]. However, not only specifically designed instruments are capable of measuring the occurrence (or absence) of an earthquake; nature herself created numerous natural seismoscopes in the form of precariously balanced rocks (PBRs) [e.g. Brune 1996, Anooshehpoor 2004]. In certain geologically preferred conditions, e.g. in California and Utah, numerous such rocks have formed. The basic concept to use these PBRs as seismoscopes is (1) to measure their shape; (2) determine a yield force or acceleration which would be necessary to topple the PBR; (3) estimate the amount of time the formation exists in its present appearance; and (4) estimate the upper limit of ground motion level (often expressed as peak ground acceleration, PGA) which has not been exceeded in this time span.

Nature has formed such seismoscopes, but they are not unique. Many ancient manmade structures are so delicate that it seems unlikely, from appearance alone, that they can remain standing even under static conditions (Figure 1). As is customarily the case in archaeoseismology, hypothesized earthquake-ruined ancient constructions are the major focus of interest, and in quantitative studies [Galadini et al. 2006, Hinzen et 

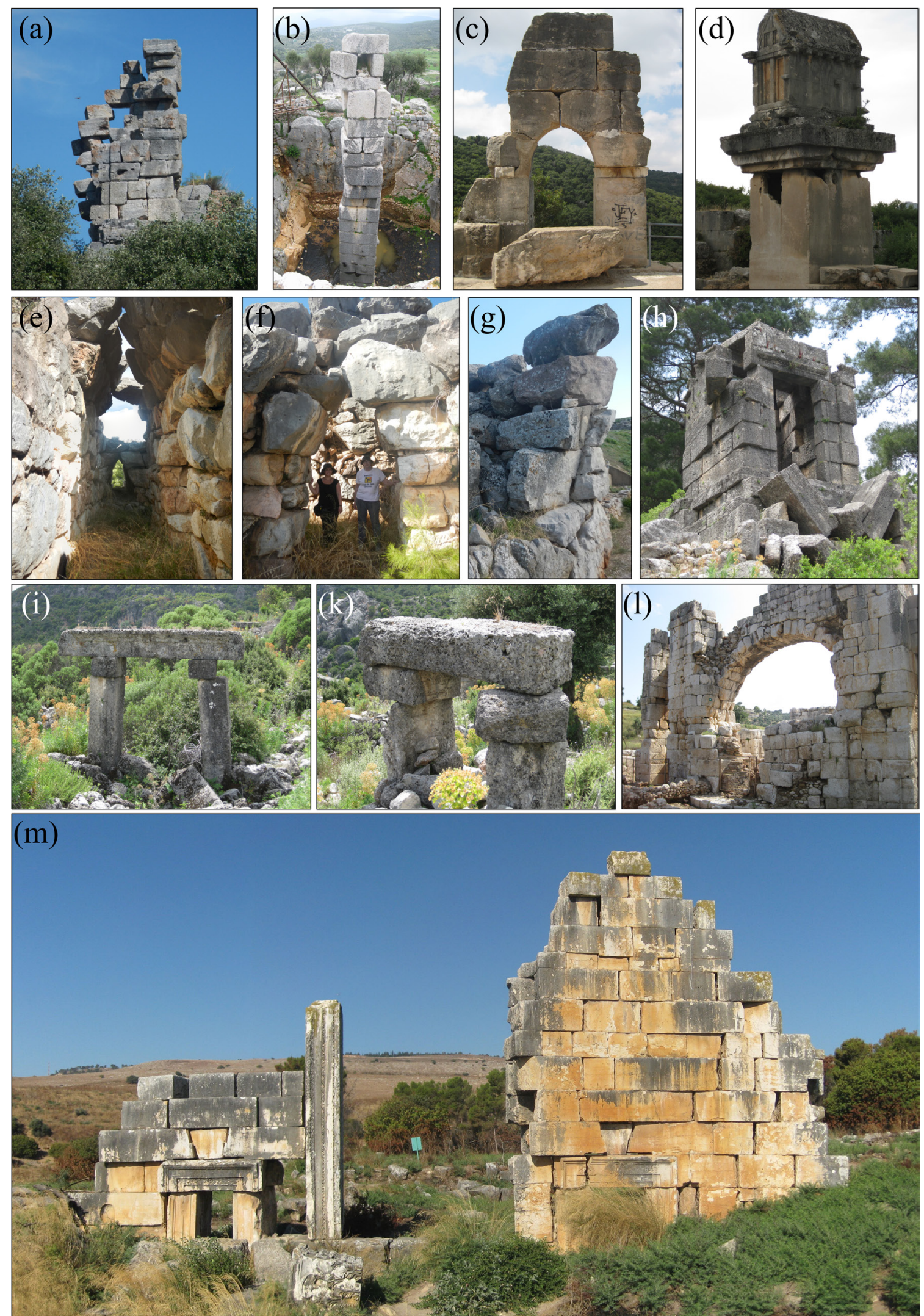

Figure 1. Examples of precariously balanced archaeological structures: (a) ruin of the Roman harbor bath in Ephesus, Turkey; (b) pre-Roman rock cistern at Patara, Turkey; (c) ruin of Montfort Crusader castle, Israel; (d) Lycien sarcophagus Xanthos, Turkey; (e+f) Mycenaean corbeled vault, Tiryns, Greece; (g) ruin of Cyclopean wall of Tiryns, Greece; (h) Roman mausoleum Pinara, Turkey; (i+k) ruins of Roman bath Pinara, Turkey; (1) delicate Roman arch, Patara, Turkey; (m) ruin of the Roman Temple, Kedesh, Israel.

al. 2009a] ground motion parameters are estimated in order to determine how and under what circumstances the constructions were damaged [Hinzen 2005, Am- braseys 2006, Hinzen 2012, 2013]. Additionally, structures such as those shown in Figure 1 can also be used as seismoscopes. We address this hypothesis and refer 
to such formations in the following as precariously balanced archaeological structures (PBASs). In order to draw conclusions about the earthquake activity in a region, or more precisely, the vibration history of a certain site, the same four steps have to be followed for the PBASs as in case of the PBRs. One advantage of the PBASs is that often the archaeological context provides more precise estimates of the time span of their existence. On the other hand, the time spans of PBASs are in general much shorter than those of PBRs. And, as the PBASs tend to be more complex than single block PBRs, sophisticated measuring and modeling is necessary to evaluate the yield ground motions. An advantage of this approach in quantitative archaeoseismology as opposed to examining ancient structures that are not PBASs, is that the often difficult task of ascertaining the pristine form of a structure before the damaging earthquake occurred is not necessary. The PBASs have to be 'merely' analyzed in their current form.

In this study, we use the ruins of a Roman Temple in Kedesh (Figure 1m), Israel, located some $4 \mathrm{~km}$ west of a branch of the Dead Sea Transform Fault (DSTF), to perform the aforementioned four steps with an emphasis on step (2) the determination of the vulnerability of the ruin. We use a Discrete Element Model (DEM) based on a 3D laser scan in combination with analytic ground motions, synthetic site specific seismograms for seven earthquake scenarios, and one measured strong motion record.

\section{Geology, Seismotectonic, Seismicity}

The DSTF (Figure 2) is the dominating tectonic feature in Israel and neighboring countries Jordan, Lebanon and Syria. The DSTF separates the Arabian plate in the east and the Sinai subplate in the west. Formed in the early Miocene, the DSTF transitions into the opening of the Red Sea (RS) Rift in the south to the Bitlis-Zagros collision zone of Arabia and Eurasia in the north [Quennell 1956, Freund et al. 1968]. Early Miocene geologic features are offset $105 \mathrm{~km}$ [Quennell 1956, Freund 1965, Bartov et al. 1980], indicating that the long term sinistral slip rate of 4-6 $\mathrm{mm} /$ year is very similar to short term geodetic rate [Wdowinski et al. 2004, Gomez et al. 2007, Sadeh et al. 2012]. The DSTF in Israel and Jordan is divided into segments named according to the valleys, from south to north: the Araba Valley (AV), the Jordan Valley (JV), and the Hula Valley (HV). These valleys connect the Gulf of Aqaba, the Dead Sea (DS) and the Sea of Galilee (SG), all pullapart basins along the DSTF (Figure 2).
North of the SG and in the HV, the faults branch into several non-parallel faults. SE-NW shortening characterizes the Lebanese Restraining Bend north of the HV. The DSTF has been seismically active since the Miocene. The instrumental record includes mainly weak to moderate-sized earthquakes [Hofstetter 2014]. In 1954, the first seismological station of Israel was installed at the Hebrew University of Jerusalem (JER). Earlier, stations in Athens, Istanbul and Cairo registered earthquakes in Israel. In the 1980s with the Israel Seismic Network (ISN) and the Jordan Seismological Observatory (JSO), two networks with short period stations were established. Over time, the networks have been upgraded with accelerometers and broadband stations. Occasionally, temporary networks were used to monitor the seismicity of the DSTF [Hofstetter 2014].

The catalogue of the Geophysical Institute of Israel (GII) lists 6821 earthquakes with magnitudes above 2.0 between 1900 to 2015 (http://www.gii. co.il last accessed 09.2015) (Figure 2). The recorded seismicity is concentrated in five spatial clusters. The first cluster, in the RS area in the south, exhibits widespread earthquake activity. Further north, the second cluster of epicenters in the AV aligns close to the DSTF. In the third cluster at the DS, the epicenters again show a wider distribution. The last two clusters are located at the JV and the HV section of the DSTF including the SG.

Recently, Wetzler and Kurzon [2016] relocated regional earthquakes of the last 30 years. The depth distribution of the relocated events shows a maximal depth of $35 \mathrm{~km}$ and a peak of the distribution at 15 $\mathrm{km}$. The strongest instrumentally recorded earthquake in 1995 occurred near Nuweiba [Baer 1999, Klinger 1999, Shamir 2003] with an $\mathrm{M}_{\mathrm{W}} 7.2$ (Figure 2). In 1927, a $M_{S} 6.2$ earthquake occurred on the western coast of the DS [Shapira 1993, Zohar and Marco 2012] and in 1956 an $M_{S} 6.0$ occurred at the SG, close to the Mediterranean coastline south of Beirut (http:/ / www. gii.co.il last accessed 09.2015).

The pre-instrumental earthquake activity of the Levante has been intensively investigated based on the area around the DSTF which is rich in cultural tradition including an abundance of historical documents and old masonry structures. In numerous historic, palaeo- and archaeoseismological studies, evidence of past earthquakes have been researched and catalogs for the last 2000 years compiled [e.g. Garfunkel 1981, Ben-Menahman 1991, Ambraseys and Barazangi 1989, Klinger et al. 2000a, Migowski et al. 2004, Wdowin- 


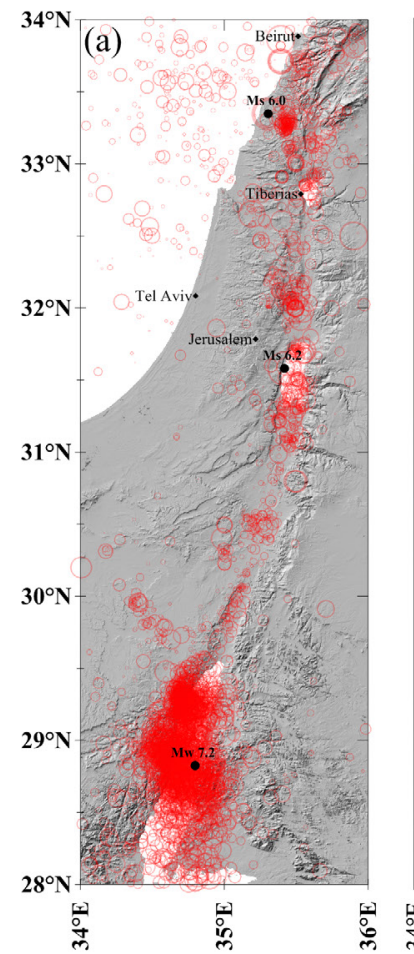

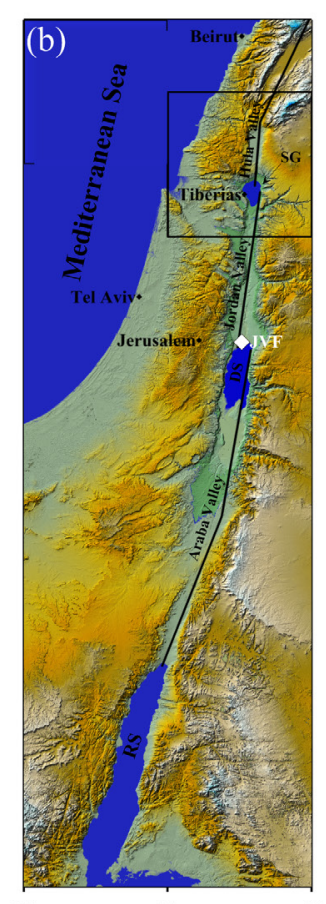

㸃

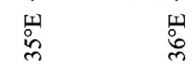

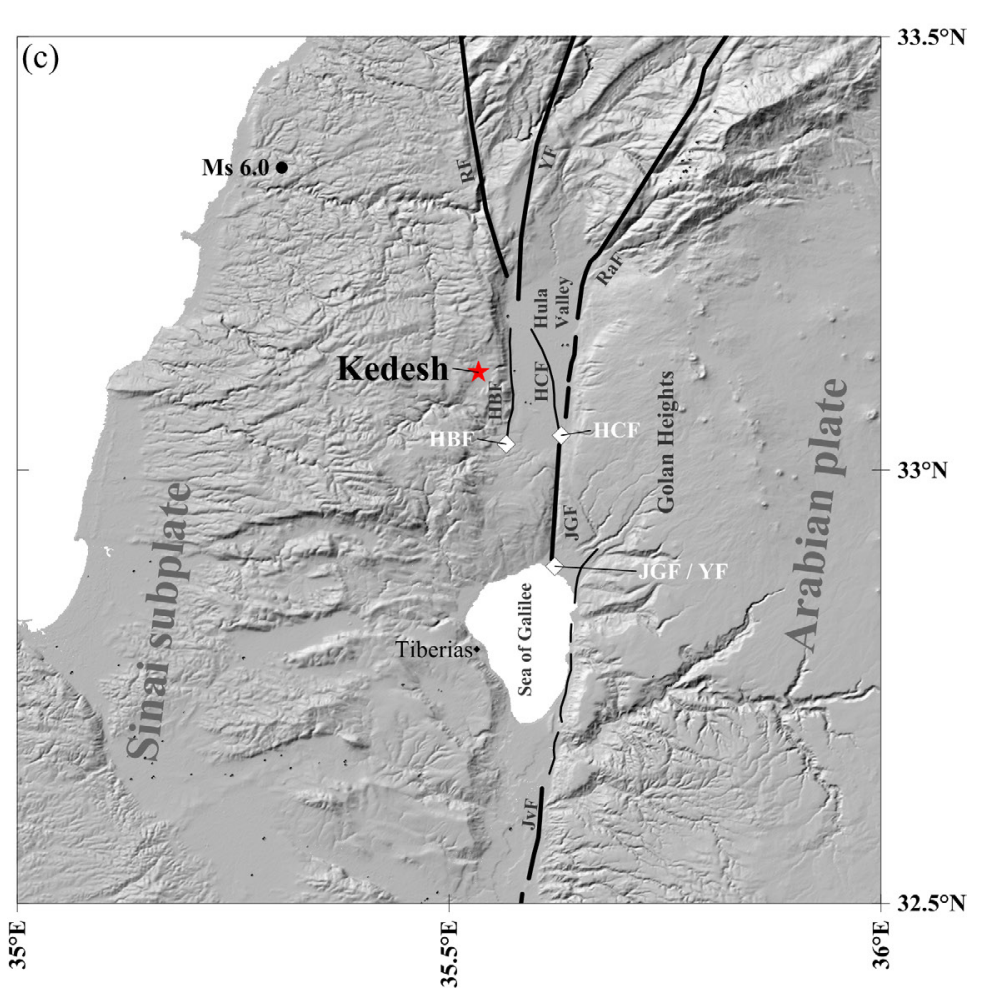

Figure 2. (a) Seismicity along the DSTF from 1900 to 2015 [www.gii.co.il last accessed 09.2015]; the diameter of the red circles scales with the magnitude of the earthquakes. The solid black circles show the epicenter the three strongest instrumentally recorded earthquakes: $M_{W}$ 7.2 Nuweiba 1996; $M_{S} 6.2$ Sea of Galilee 1927; $M_{S} 6.0$ north of Sea of Galilee 1956. (b) Digital terrain map of the DSTF (black lines). The white rhombus marks the epicenter of the synthetic JVF earthquake labeled in white. The black rectangle indicates the area of the detailed map in (c), the red star marks the location of the Roman Temple of Kedesh. Black lines show the local active faults of the area [after Wechsler et al. 2014] (JvF = Jordan Valley Fault, JGF = Jordan Gorge Fault, HCF = Hula Valley Central Fault, HBF = Hula Valley Border Fault, RaF $=$ Rachaya Fault, RF $=$ Roum Fault, $\mathrm{YF}=$ Yammouneh Fault). The white rhombuses mark the epicenters of the sources used to calculate synthetic seismograms labeled in white.

ski et al. 2004, Marco et al. 2005a , Marco and Klinger 2014, Ellenblum 2015]. In total, 31 pre-instrumental earthquakes could be identified (Table 1).

\section{Kedesh Temple, History and Structure}

The Roman Temple of Kedesh was constructed as a long lasting project through the $2^{\text {nd }}$ and $3^{\text {rd }}$ century CE. It is located on a mound $25 \mathrm{~km}$ north of the SG and $4 \mathrm{~km}$ east of the HBF (Figure 2), a western branch of the DSTF. The original temple area included a cella, the inner chamber of the temple, of $20.66 \mathrm{~m} \times 22.63 \mathrm{~m}$ and a portico and was encircled by a large temenos [Fischer et al.1984]. It has been aligned east-west with the entrance facing east just opposite the main entrance of the temenos. Its well-worked ashlars are made of limestone and dolomite [Fischer et al. 1984]. Mortar was not used to support the construction.

The only persisting standing walls are two sections of the temple front (Figure 1m, Figure 3a). The roof and the rest of the temple walls are missing though a rather large amount of tiles found in the excavation points to the roofing of the temple or at least part of it. Parts of the cella foundation are still visible. The two remaining sections of the front wall are separated by a $3.33 \mathrm{~m}$ gap of the former ceremonial gate. The northern and southern sections have a remaining height of $7.26 \mathrm{~m}$ and $3.59 \mathrm{~m}$ respectively. Each section includes a smaller entrance for worshippers. The southern doorjamb of the main gate is still in situ; however, the northern one and the lintel are missing. Both wall-sections are double shell ashlar masonry, and some ashlars are oriented orthogonal to the wall trend and connect the shells to increase stability. The wall is pseudoisodomic, i.e. within rows all ashlars are of equal height, but among rows the heights differ. The northern wall has a concave bend to the east. The blocks at the foundation of the structure are currently buried in the ground and the foundation line is not leveled over the length of the construction. Sediments from a slope dipping from north to south have buried some blocks of the northern wall (Figure 3a).

Fischer et al. [1984] suggest the temple was destroyed by an earthquake on May 19, 363 C.E. Unearthed ceramics and coins show that the temple was abandoned after the earthquake. An early photo of the ruin (Figure 3d) taken by Kitchener during his Survey 


\begin{tabular}{|c|c|c|c|}
\hline \# & Reference & Segment & $\begin{array}{c}\text { Achievement Earthquake*/Slip } \\
\text { Rate (SR)/ Last Event (LE)/ } \\
\text { Recurrence (Re) }\end{array}$ \\
\hline 1 & Reches and Hoexter [1981] & S. Jordan Valley & $31 \mathrm{BCE}, 747$ \\
\hline 2 & Marco And Agnon [1995] & Dead Sea & $\operatorname{Re}$ \\
\hline 3 & Amit et al. $[1996,1999,2002]$ & Southern Arava & $\operatorname{Re}$ \\
\hline 4 & Marco et al. [1997, 2005b]; Elleblum et al. [1998] & Jordan Gorge & 1202,1759 \\
\hline 5 & Galli [1999] & Arava-Jordan-Hula Valley & \\
\hline 6 & Enzel et al. [2000] & Dead Sea & $\operatorname{Re}$ \\
\hline 7 & Klinger et al. [2000a] & Northern Arava & 1212 \\
\hline 8 & Klinger et al. [2000b] & Northern Arava & SR \\
\hline 9 & Niemi et al. [2001] & Northern Arava & SR \\
\hline 10 & Zilbermann et al. [2000] & Hula Valley & \\
\hline 11 & Gomez et al. [2001, 2003] & Serghaya Fault & 1705 or $1759 /$ \\
\hline 12 & Meghraoui et al. [2003] & Misyaf, Yammouneh & \\
\hline 13 & Marco et al. [2003] & Sea of Galilee & 749 \\
\hline 14 & Daëron et al. [2004, 2005, 2007] & South Yammouneh & 1202 \\
\hline 15 & Zilberman et al. [2005] & South Avara & $3 / 1068 /$ \\
\hline 16 & Marco et al. $[2005 b]$ & Jordan Gorge & $1202,1759 / \mathrm{LE} / \mathrm{SR}$ \\
\hline 17 & Chorowicz et al. [2005] & Yammouneh & SE \\
\hline 18 & Akyuz er al. [2006] & Northern Yammouneh & $859,1408,1872$ \\
\hline 19 & Nemer and Meghraoui [2006] & Roum Fault & $1837, \mathrm{SR}$ \\
\hline 20 & Haynes et al. [2006] & Northern Arava & 634 or $659 / 660,873,1068$ and 1546 \\
\hline 21 & Elias et al. [2007] & Lebanon thurst & 551 \\
\hline 22 & Thomas et al. [2007] & Aqaba & \\
\hline 23 & Ferry et al. [2007] & Jordan Valley & SR \\
\hline 24 & Le Beon et al. [2008] & Arava & \\
\hline 25 & Nemer et al. [2008] & Rachaya and Serghaya faults & 1759 \\
\hline 26 & Makovsky et al. [2008] & Elat Fault & SR \\
\hline 27 & Altunel et al. [2009] & S. Turkey & SR \\
\hline 28 & Le Beon et al. [2010] & Arava & $S R$ \\
\hline 29 & Karabacak et al. [2010] & Northern Yammouneh & SR \\
\hline 30 & Ferry et al. [2011] & Jordan Valley & SR, Re, LE \\
\hline 31 & Le Beon et al. [2012] & Arava & SR \\
\hline
\end{tabular}

Table 1. List of on-fault palaeoseismic investigations at the DSTF system arranged by year of publications [after Marco and Klinger 2014]. Bold letters indicate earthquakes used to simulate ground motions in this study. ${ }^{*}$ unless indicated different all dates are Common Era (CE).

of Western Palestine (1871 - 1878), shows that most parts of the temple were already missing at that time. Comparing the photo, which was published in Conder and Kitchner [1882] (Figure 3d), with the current state (2013) of the structure (Figure 3c) reveals some alterations to the southern wall. The ashlars highlighted in Figure $3 \mathrm{~d}$ have vanished over the past 14 decades. As none of the ashlars can be found next to the wall and they were likely easily accessible to looting, it can be assumed that they were taken from the site for secondary use. Some archaeologists assume that the whole temple was used as a quarry after it was abandoned as evidenced by large fragments of the temple found atop the Tel Kedesh, the ancient city, and in some of the set- 

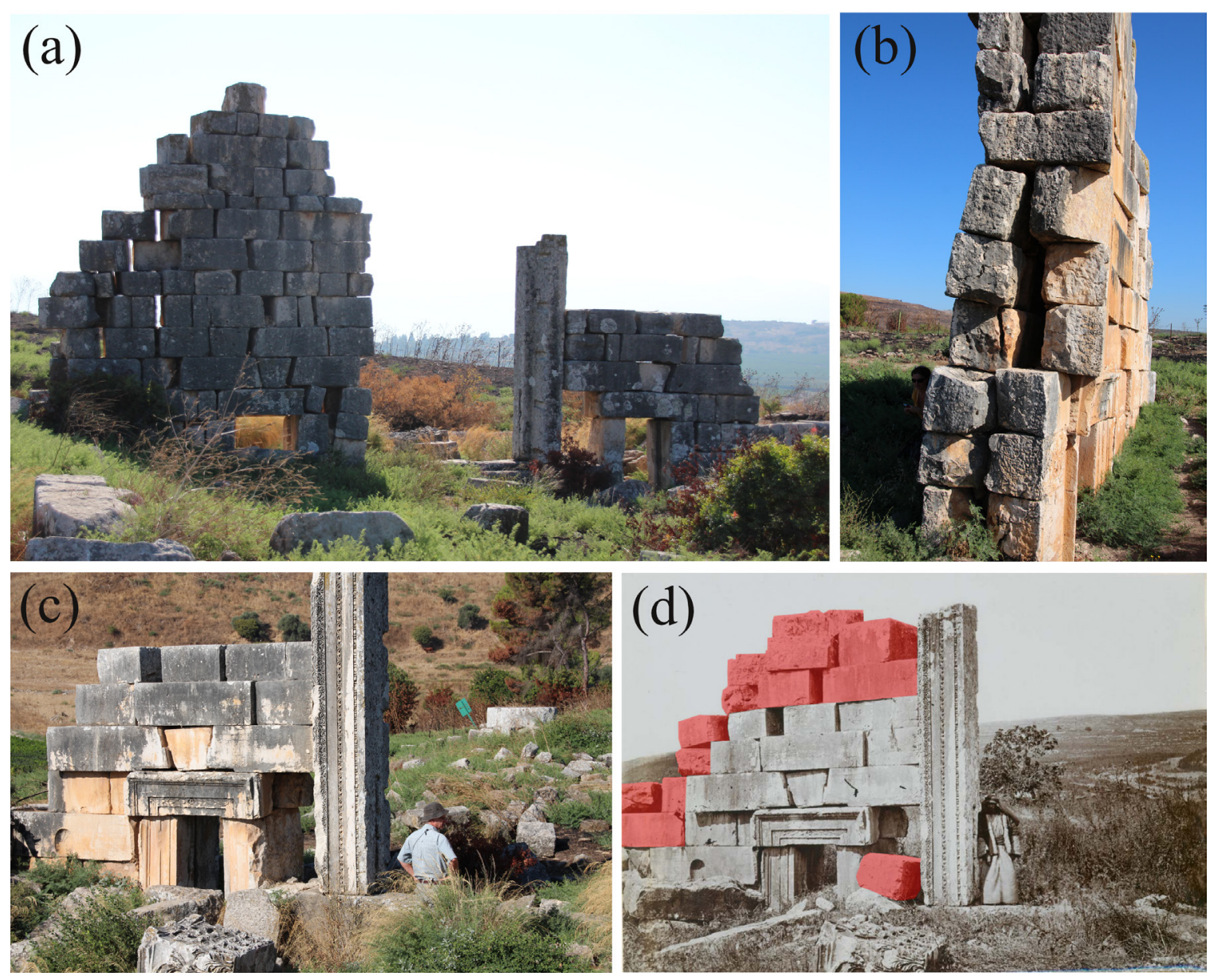

Figure 3. (a) View from west towards the remains of the Roman Temple of Kedesh. The northern and southern sections have heights of $7.26 \mathrm{~m}$ and $3.59 \mathrm{~m}$, respectively. The door-jamb at the southern section is $4.4 \mathrm{~m}$ high. (b) View from the south to the northern section showing the gap between the two shells. (c) Photo showing the current state of the southern section of the ruin (Photos: Schweppe). (d) Photo by Kitchener from 'The Survey of Western Palestine' [Conder and Kitchener 1882]. The red highlighted ashlars are missing today.

tlements of the surrounding. Fenner [1905] has documented that local inhabitants wanted to annoy scientists studying the temple by trying to overturn some blocks. With this background, it is not possible to differentiate with certainty which damage is of anthropogenic or of natural cause. However, the wall in Figure 3a shows horizontal shifts and gaps between the ashlars which indicate that, at least in part, dynamic shaking has ruined the Kedesh Temple. In particular, we interpret the gaps between the ashlars in the northern section and its bend as the consequence of earthquake ground motions.

\section{Modeling}

Laser scanning technology has become a common tool in archaeoseismology [Schreiber et al. 2012, Fleischer et al. 2010, Hinzen et al. 2012]. It combines the advantages of fast, non-invasive field application, high precision, and safe and easy measuring of distances, angles, surfaces and volumes. For the PBAS of the Roman Temple of Kedesh, we used a phase scanner set up at 24 locations (including the top of the temple) to capture the complete structure with only minor shadow- ing effects. Vegetation close to the walls was removed to create an undistorted view, particularly to the foundation line of the structure. Checkerboards and $0.25 \mathrm{~m}$ diameter spheres were used as markers for referencing the scans. The resulting $3 \mathrm{D}$ model of the temple has a mean target tension of $0.0026 \mathrm{~m}$ and contains more than 80 million points. Figure 4 shows a view from the West towards the point cloud of the virtual model of the ruin and the corresponding perspective view to the DEM. One challenge in designing and displaying the scans was the double wall nature of the temple front requiring painstaking attention to detail in order to gather sufficient data for reconstruction of the inner wall. A total of 141 ashlars were identified from the point cloud in combination with the digital photographs. The 3D coordinates of the vertices of these ashlars were determined. Individual blocks in the model have between 8 and 24 vertices. The size ranges from 0.06 to $2.62 \mathrm{~m}^{3}$, resulting in a mass of 151 to $6306 \mathrm{~kg}$ estimating a uniform density of $2400 \mathrm{~kg} / \mathrm{m}^{3}$.

After the raw modeling of the ashlars, fine-tuning to precisely align corners of adjacent blocks was neces- 
sary to avoid any unrealistic penetration of one block into another which would lead to unrealistic stresses in the DEM and instability or even uncontrolled 'explosion' of the model. Ashlars with complex structure had to be combined from several simply structured shapes, so that all of these by themselves were of concave shape. This important precondition was necessary to ensure edge detection and provide collision control in some DEMing codes.

The first version of the model was created in 3DEC (see data and resources) a software initially written for rock-mechanical applications and based on the discrete element method by Cundall [1988], Hart and Cundall [1988], Cundall and Hart [1992]. 3DEC's built-in scripting language is a powerful tool for model creation and simulations. Custom written routines facilitated importing the vertices, surveyed with the laser scan, and created the according blocks. In 3DEC, advanced rock mechanical properties can be applied to the discrete objects. To analyze the dynamic behavior of structures with models containing numerous objects, the damping parameters must be set to rather low values to achieve a reasonable runtime [Psycharis et al. 2003]. Otherwise, the timesteps for calculation cycles become impractically small. Due to the low damping parameters, the objects become bouncy and the options of monitoring internal movement and collapse mechanisms are therefore limited.

As shown by Hinzen and Montabert [this issue] the software development tool UNITY (see data and resources) is capable of modeling the dynamic behavior of wall-type structures including their internal deformation and collapse pattern. For verification, the authors

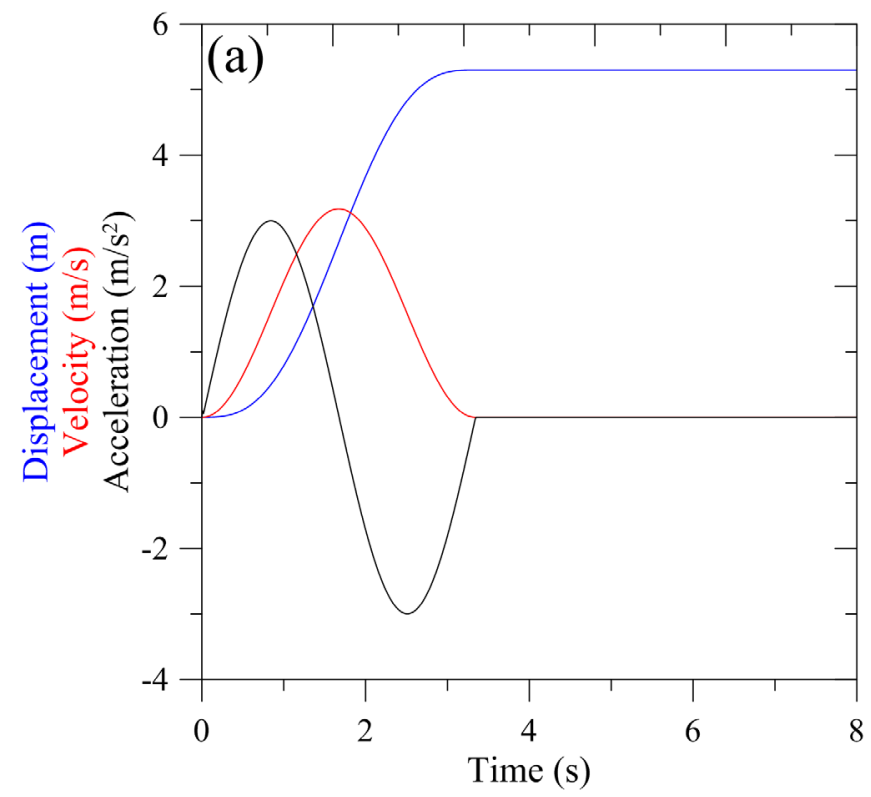

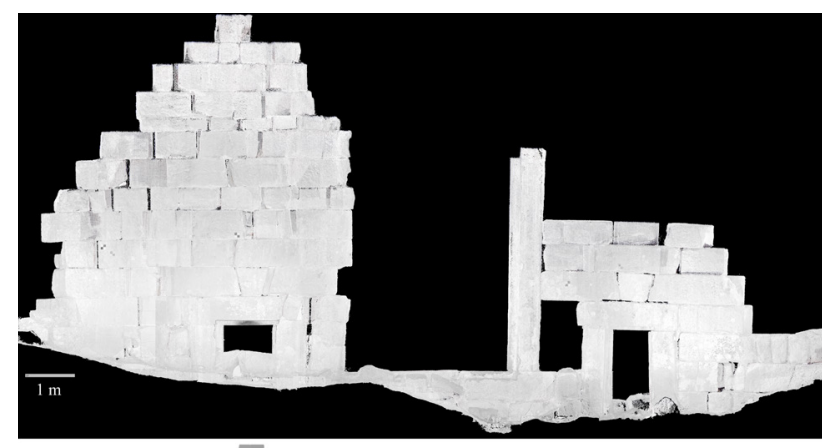

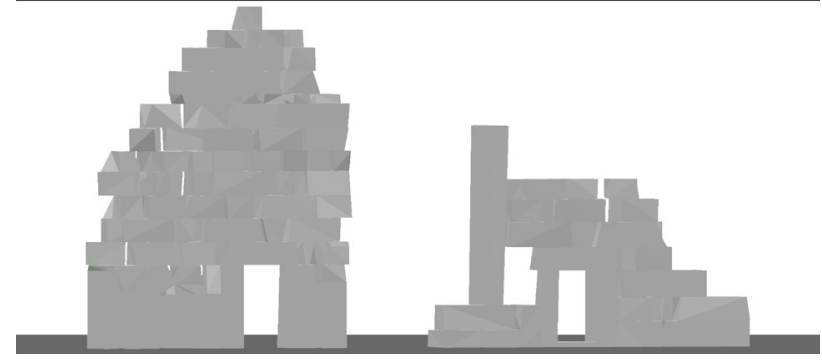

Figure 4. Top: Ortho-view of the laser scan point cloud of the ruin the Roman Temple of Kedesh from west towards east. Bottom: Same view to the discrete element model of the temple remains.

compared the calculated movement of a rocking block with the equations presented by Housner [1963] and the average amplitude misfit for the first 25 extremal values of the displacement of the rocking block was $0.7 \%$. They found a time step of $0.001 \mathrm{~s}$ as suitable for such calculations. Compared with 3DEC, UNITY is lacking many of the rock mechanical features. However, UNITY, originally developed for game design, it is highly customizable. To detect collision between two objects, colliders are assigned to each object. If a collision is detected, contact points between the two shapes are generated. The energy dissipation during a collision

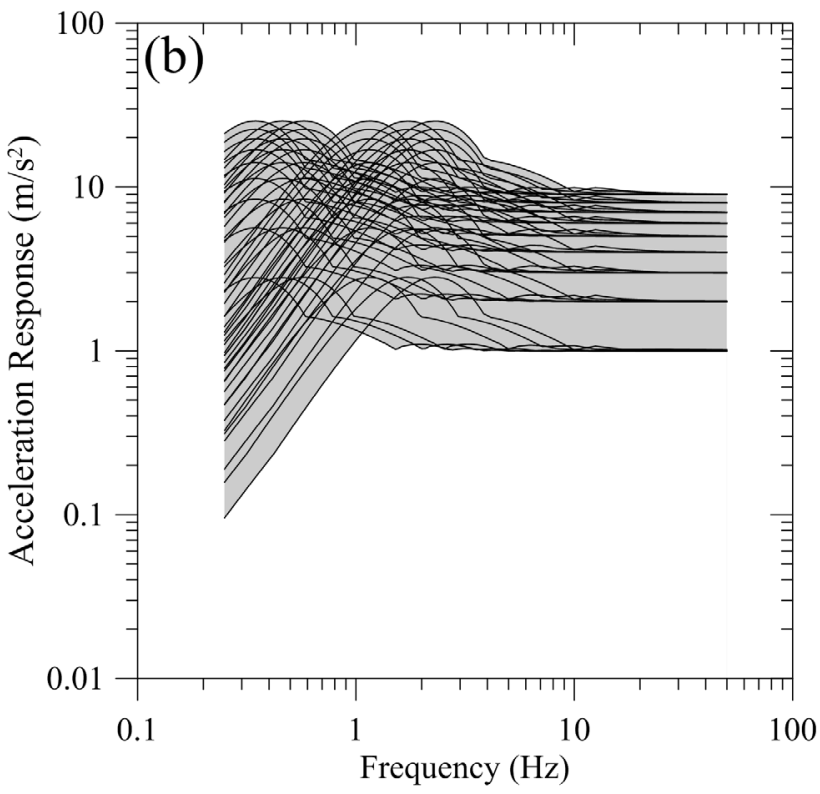

Figure 5. (a) Time-series of a cycloidal pulse with a frequency of $0.3 \mathrm{~Hz} @$ PGA of $3 \mathrm{~m} / \mathrm{s}^{2}$. (b) Acceleration response spectra of 54 cycloidal impulses used to test the dynamic behavior of the model of the Roman Temple of Kedesh. 


\begin{tabular}{|c|c|c|c|c|c|c|c|c|}
\hline & ID & Year & $\mathbf{M}$ & Latitude & Longitude & $\begin{array}{c}\text { Epicentral } \\
\text { Distance }(\mathbf{k m})\end{array}$ & Comp. & $\operatorname{PGA}\left(\mathrm{m} / \mathrm{s}^{2}\right)$ \\
\hline & & & & & & & $Z$ & 1.57 \\
\hline \multirow[t]{3}{*}{1} & $\mathrm{HBF} \dagger$ & - & 5.8 & 33.0300 & 35.5660 & 12.6 & $\mathrm{~N}$ & 1.08 \\
\hline & & & & & & & E & 1.87 \\
\hline & & & & & & & $Z$ & 0.60 \\
\hline \multirow[t]{3}{*}{2} & $\mathrm{HCF} \dagger$ & - & 5.9 & 33.0400 & 35.6300 & 9.9 & $\mathrm{~N}$ & 1.10 \\
\hline & & & & & & & $\mathrm{E}$ & 1.22 \\
\hline & & & & & & & Z & 0.29 \\
\hline \multirow[t]{3}{*}{3} & JVF & 749 & 7.4 & 31.7682 & 35.5096 & 149.2 & $\mathrm{~N}$ & 2.49 \\
\hline & & & & & & & E & 0.46 \\
\hline & & & & & & & $z$ & 1.75 \\
\hline \multirow[t]{3}{*}{4} & YF & 1202 & 7.6 & 32.8888 & 35.6226 & 26.5 & $\mathrm{~N}$ & 2.48 \\
\hline & & & & & & & $\mathrm{E}$ & 5.00 \\
\hline & & & & & & & $Z$ & 0.20 \\
\hline \multirow[t]{3}{*}{5} & JGF & 1759 & 6.1 & 32.8888 & 35.6226 & 26.5 & $\mathrm{~N}$ & 0.66 \\
\hline & & & & & & & E & 0.33 \\
\hline & & & & & & & Z & 0.25 \\
\hline \multirow[t]{3}{*}{6} & $\mathrm{RaF}$ & 1759 & 7.1 & 33.2547 & 35.6873 & 21.5 & $\mathrm{~N}$ & 0.92 \\
\hline & & & & & & & E & 0.81 \\
\hline & & & & & & & Z & 0.53 \\
\hline \multirow[t]{3}{*}{7} & RoF & 1837 & 6.8 & 33.1890 & 35.5568 & 8.7 & $\mathrm{~N}$ & 3.42 \\
\hline & & & & & & & E & 0.72 \\
\hline & & & & & & & Z & 7.13 \\
\hline \multirow[t]{2}{*}{8} & $\mathrm{Tai}^{*}$ & 1999-09-20 & 7.7 & 23.8500 & 120.8200 & 31.7 & $\mathrm{~N}$ & 8.37 \\
\hline & & & & & & & E & 7.93 \\
\hline
\end{tabular}

Table 2. Parameters of two assumed earthquakes ( $\dagger)$, five historic earthquakes along the DSTF and in addition a strong motion record $(*)$ from the 1999 Taiwan earthquake.

is defined by a coefficient of restitution, in our case 0.86 ; friction follows a coulomb friction model. With UNITY it is possible to observe the collapsing structure and internal deformation with a reasonable calculation time not least due to its GPU processing capabilities. The model, composed of 142 discrete objects, containing 141 ashlars and the baseplate, was exported from 3DEC and subsequently converted with Blender (see data and resources) into a UNITY-readable file-format. To represent the buried ashlars at the foundation of the ruin, the according objects in the model were fixed to the baseplate by setting the break force of the joints to infinity. The dynamic and static coefficient of friction for all other joints between the blocks was set to 0.6 .

\section{Calculations}

Analytic ground motion signals in form of cycloidal pulses [Zhang and Makris 2001] were chosen for a first series of test calculations. These signals have previously been applied in archaeoseismology [Hinzen 2009b, Hinzen and Montabert this issue]; they fulfill the boundary condition of zero displacement, velocity and acceleration at the start of the calculations and zero velocity and acceleration at the end. The displacement history can be seen as a simple version of a horizontal ground motion close to a strike slip fault [Hinzen and Montabert this issue]. The response spectra of the 54 impulses which were applied only in the horizontal directions (parallel and orthogonal to the wall trend) are shown in Figure 5. Major frequencies of the signals were in the range from 0.3 to $5.0 \mathrm{~Hz}$ and PGA ranged from 1 to $9 \mathrm{~m} / \mathrm{s}^{2}$.

Further, eight earthquake scenarios were used, five of which resemble historical earthquakes along the DSTF, two are local speculative events in the HV in close proximity to the Kedesh site, and the last signal is a measured strong motion record of the $\mathrm{M}$ 7.7 Chi Chi earthquake in Taiwan. The 1999 Chi Chi earthquake was chosen (1) because it was recorded in close proximity to the epicentre; (2) earthquakes with M 7.7 are possible in the study region; and (3) the large PGA provided a chance to double-check if the model does simulate failure of the remains cor- 

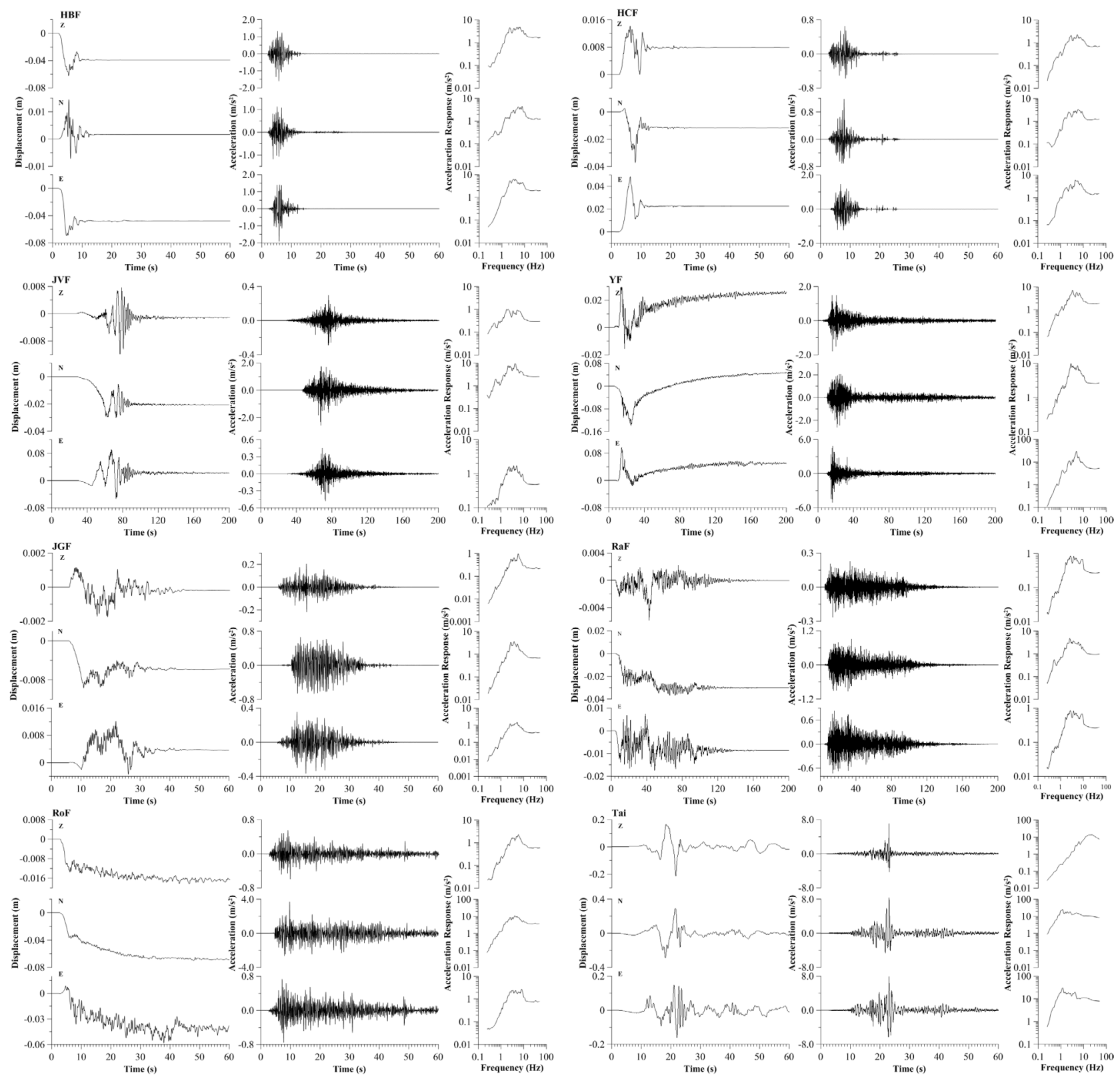

Figure 6. Displacement and acceleration time series and acceleration response spectra of the earthquake ground motions used in the calculations. The earthquake source code given in the upper left of each figure corresponds to the list in Table 1. In addition magnitude and minimum distance to the surface trace of the faults $\left(\mathrm{D}_{\min }\right)$ are: $\mathrm{HBF}_{\mathrm{w}} 5.76, \mathrm{D}_{\min } 4.2 \mathrm{~km} ; \mathrm{HCF} \mathrm{M}_{\mathrm{w}} 5.85, \mathrm{D}_{\min } 7.9 \mathrm{~km} ; J V F \mathrm{M}_{\mathrm{w}} 7.39$, $\mathrm{D}_{\min }$ $32.5 \mathrm{~km} ; \mathrm{YF} \mathrm{M}_{\mathrm{w}}$ 7.62, $\mathrm{D}_{\min } 6.4 \mathrm{~km}$; JGF $\mathrm{M}_{\mathrm{w}} 6.14, \mathrm{D}_{\min } 13.6 \mathrm{~km} ; \operatorname{RaF~M}_{\mathrm{w}} 7.06, \mathrm{D}_{\min } 21.7 \mathrm{~km} ; \operatorname{RoF}_{\mathrm{w}} 6.8, \mathrm{D}_{\min } 9.0 \mathrm{~km} ; \mathrm{Tai}, \mathrm{M} 7.7$.

rectly. Table 2 summarizes the parameters of the earthquakes which were modeled with one to three fault segments. All segments were assumed to have left-lateral movement as the DSTF in total. The second segment of the $749 \mathrm{JVF}$ earthquake has a dip of $70^{\circ}$; all other segments in the model dip with $90^{\circ}$. The largest of the historical earthquakes dated to $1202 \mathrm{had} \mathrm{a} \mathrm{M}_{\mathrm{W}}$ of 7.6. The rupture is modeled along three fault segments following the Jordan Gorge Fault (JGF), the Hula Valey Cental Fault (HCF) and the Yammouneh Fault (YF). The epicenters of the assumed and historical earthquakes are shown in Figure $2(\mathrm{~b}, \mathrm{c})$.
Green's functions were calculated on the basis of a crust model by the Geophysical Institute of Israel (GII) [2013] and the earthquake source is represented by an arbitrary number of rectangular dislocation planes [Wang 1999]. The geometry for each segment was simplified from the maps shown in Figure 2 and the seismic moment was estimated based on the surface rupture length following Wells and Coppersmith [1994]. Subsources are distributed on each segment following a Gutenberg Richter law. Figure 6 shows the synthetic displacement and acceleration seismograms of the seven scenarios as well as the corresponding response spectra. 


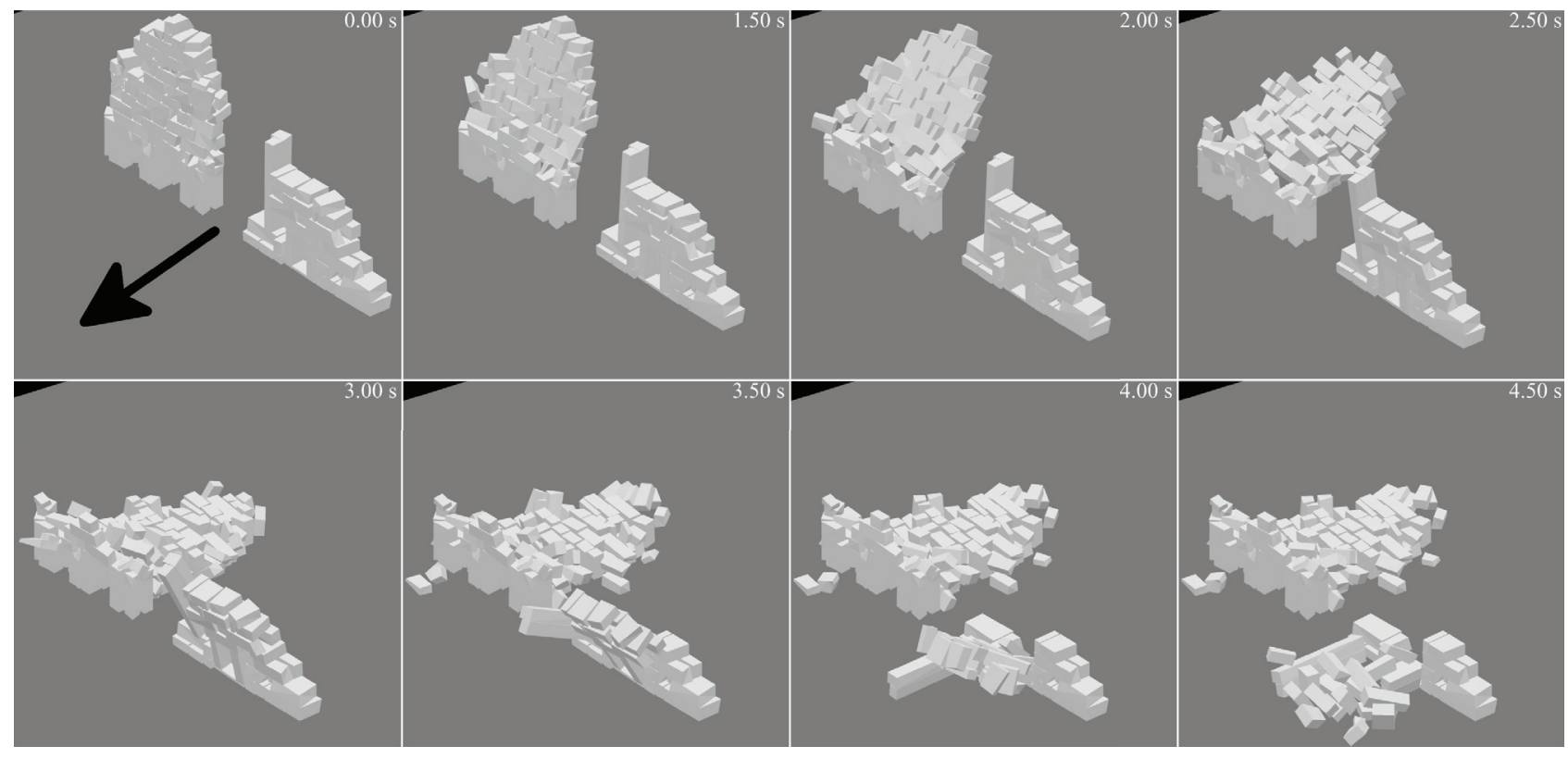

Figure 7. Snapshots of the collapsing walls of the Roman Temple of Kedesh during a horizontal ground motion in form of a cycloidal pulse with a frequency of $0.3 \mathrm{~Hz}$ at a PGA of $3 \mathrm{~m} / \mathrm{s}^{2}$ at consecutive times. The black arrow in the first snapshot indicates the direction of the impulse from east to west; the time of each snapshot is given in the upper right corner.

\section{Results}

Figure 7 shows snapshots of the simulation with a cycloidal pulse with a PGA $3 \mathrm{~m} / \mathrm{s}^{2}$ and frequency $0.3 \mathrm{~Hz}$ applied as ground-motion orthogonal to the wall trend (the simulation is available as animation in the electronic supplements to this article). The movement of the pulse lasts 3.3 seconds. In this specific case two failure mechanisms affect the two wall sections. The southern (smaller) wall is falling in direction of the ground-motion during its stopping phase (denoted as first failure mechanism in the following). The northern wall topples in the opposite direction, due to the inertial forces during the starting phase of the pulse (second failure mechanism).

In order to quantify the effect of the ground motions, we monitored the motion of the center of geometry of all ashlars during the time window of the modeling, which lasted $7 \mathrm{~s}$ for the analytic impulses and $10 \mathrm{~s}$ longer than the earthquake records in order to allow all moving ashlars to settle. The length of a vector connecting the original position of each ashlar with its final resting position, i.e. the modulus of displacement vector (MDV) [Hinzen 2009b, Hinzen and Montabert this issue] is used as a measure for the overall deformation. In Figure 8 the MDVs of all ashlars are shown together with a summary of their distribution in form of box plots of the MDVs separate for the northern and southern section of the wall.

As an example, the results using an impulse with $0.3 \mathrm{~Hz}$ frequency and $3 \mathrm{~m} / \mathrm{s}^{2}$ PGA are given in Figure 8 (a). Figures 8 b,c summarize the results of 54 tests in a matrix of six frequencies and nine PGAs. They show that higher ground motion amplitudes are necessary to topple the walls when the frequency of the impulses increases; a diagonal is separating the damaged from the surviving cases. It is also evident that the northern (taller) wall is more vulnerable at lower frequencies than the southern (smaller) wall. For a PGA of $1 \mathrm{~m} / \mathrm{s}^{2}$, no toppling occurs at frequencies between 0.3 and $2 \mathrm{~Hz}$; at $2 \mathrm{~m} / \mathrm{s}^{2}$, the northern wall topples while the southern wall survives the test. The toppling occurs to the left which is the direction of the ground motion (directed from east to west), i.e. the first failure mechanism. The next row of plots in Figure 8 for a PGA of $3 \mathrm{~m} / \mathrm{s}^{2}$ shows a changeover of the toppling to the right, i.e. the second failure mechanism. However, as at frequencies above $0.3 \mathrm{~Hz}$ and PGA above $3 \mathrm{~m} / \mathrm{s}^{2}$, the shorter wall still undergoes first mechanism failure. At larger PGAs the frequency increases at which the change of the failure mechanism from the first to the second occurs in case of the smaller wall. The transition from the first to the second failure mechanism occurs at $0.4 \mathrm{~Hz}$ by $5 \mathrm{~m} / \mathrm{s}^{2}$. At $0.5 \mathrm{~Hz}$, the ashlars of the smaller wall fall to both sides, indicating that this parameter combination falls just in-between the two failure modes at PGAs between $5-7 \mathrm{~m} / \mathrm{s}^{2}$. The experiments with a frequency of $1 \mathrm{~Hz}$ show that here the smaller wall starts toppling at $4 \mathrm{~m} / \mathrm{s}^{2}$ with the first failure mechanism, while the larger wall topples at $6 \mathrm{~m} / \mathrm{s}^{2}$ with the second mechanism. In some cases, close to the diagonal of the matrix in Figure 8 separating the collapse from non-collapse (e.g.5 m/s²@1 Hz), a few 
(a) $0.3 \mathrm{~Hz} @ 3 \mathrm{~m} / \mathrm{s}^{2}$

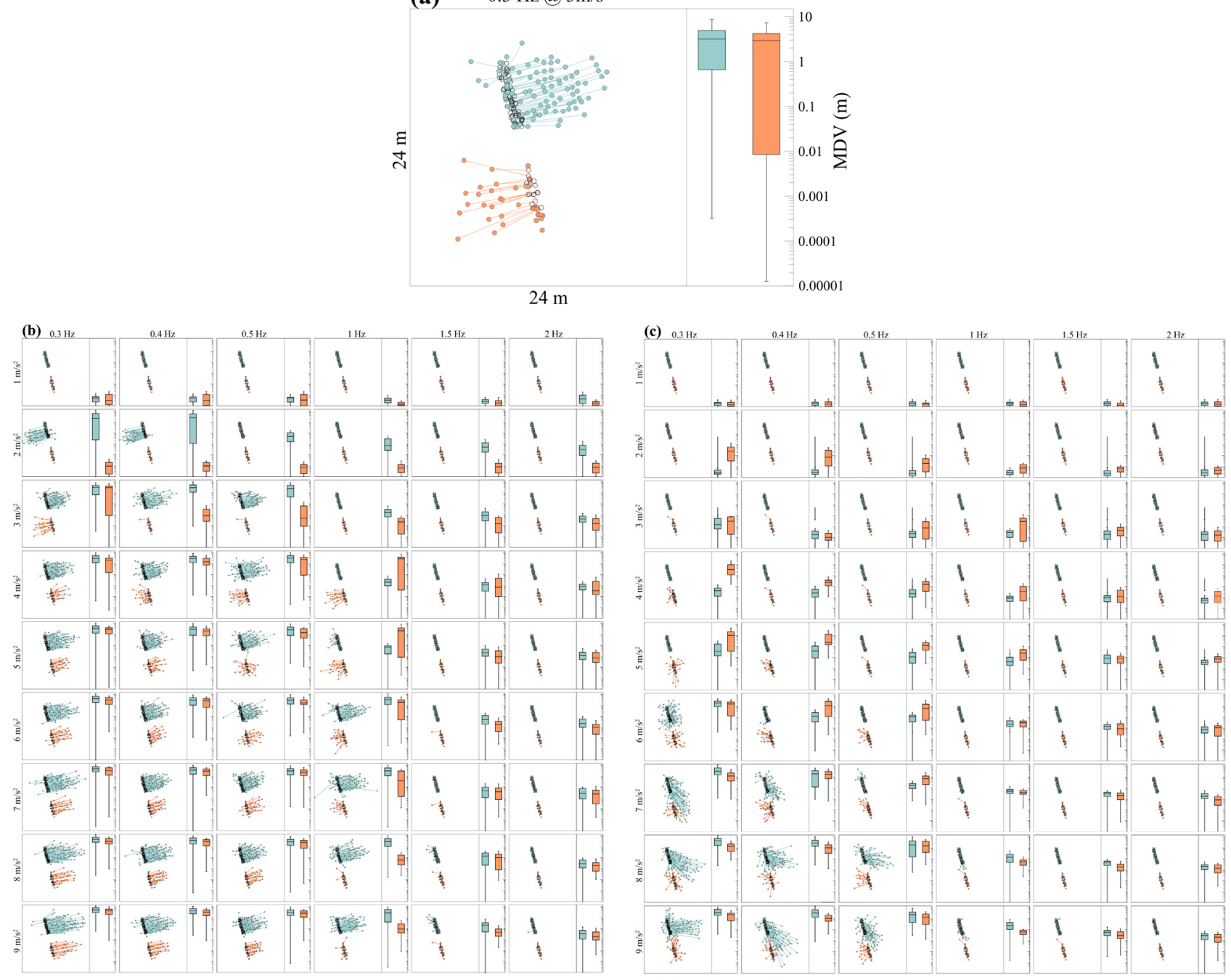

Figure 8. Final resting positions of building ashlars at the end of the application of cycloidal pulses. (a) shows the result of the horizontal ground motion orthogonal to the wall for a cycloidal pulse with $0.3 \mathrm{~Hz} @ 3 \mathrm{~m} / \mathrm{s}^{2}$. The plot on the left is a bird eyes view (map $24 \times 24 \mathrm{~m}$ ) of the model. The colored lines connect the starting (open circles) and end positions of the block's center of gravity; blue and orange for the northern and southern section of the wall, respectively. The length of the lines corresponds to the modulus of the final displacement vector (MDV). The graphs on the right side of the map show box plots with the distribution of the MDVs in a logarithmic scale from 0.00001 to $15 \mathrm{~m}$. The colored sections indicate the range from the first to the third quartile of MDVs, the horizontal line indicates the median and the lines with the whiskers give the minimum and maximum MDV values for each experiment. Panels (b) and (c) show the results of horizontal ground motions orthogonal and parallel to the wall trend, respectively. Rows and columns of the panels give the PGA and main frequency of the pulses, respectively, as indicated at the left and top border. Each individual graph has the same scaling as the graphs in (a).

falling ashlars indicate the higher vulnerability of the edges of the walls. At the higher frequencies of $1.5 \mathrm{~Hz}$ and $2 \mathrm{~Hz}$, a clear increase of the internal deformation with increasing PGAs is expressed by the increasing median values of the MDVs for both wall sections. However, only a few ashlars from the edges fall down at the largest PGAs tested.

As expected, the vulnerability of both walls is much smaller for ground motion in a north-south direction, parallel to the wall trend (Figure $8 \mathrm{~b}$ ). Here PGAs above $6 \mathrm{~m} / \mathrm{s}^{2}$ are necessary to initiate major collapsing of ashlars. While the downfall directions for the smaller wall are varied, the majority of toppling blocks from the higher wall fall in the direction of the ground motion, indicating the first failure mechanism. It is noticeable that at PGAs of 4 and $5 \mathrm{~m} / \mathrm{s}^{2}$, blocks start dropping out of the smaller wall, a result which is not observed in case of the taller wall.

None of the simulated earthquake ground motions initiates a collapse of the ruin; only internal deformation of the model is observed. As shown in Table 2 for the historical earthquakes JVF, JGF, RaF and RoF, the largest PGA occurs consistently in the north-south direction, the direction in which the walls are least vulnerable (Figure 8). Furthermore PGAs do not exceed $4 \mathrm{~m} / \mathrm{s}^{2}$. The only exception is the largest 


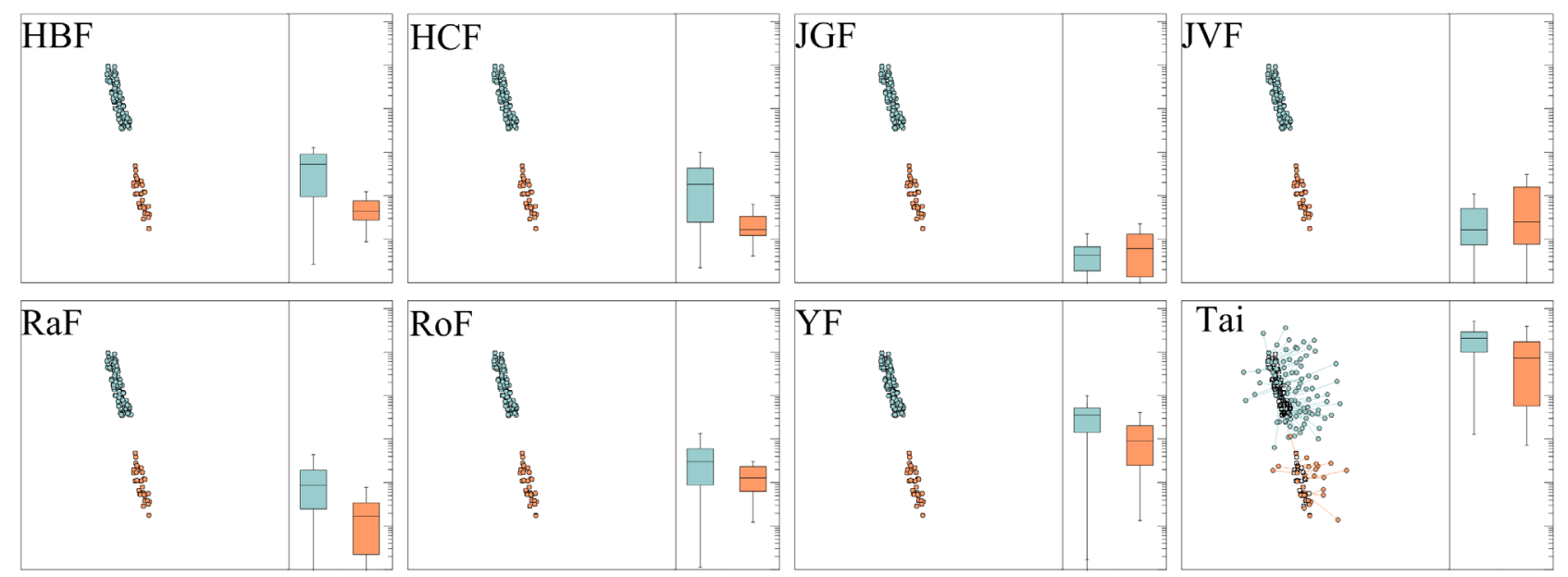

Figure 9. Final resting positions of building ashlars at the end of the application of the earthquakes. Each individual graph shows the results for one earthquake ground motion. The codes in the upper left corner indicate the earthquakes which are listed in Table 2. See caption of Figure 8 for scale and details.

historical earthquake (YF) where the largest PGA of $5 \mathrm{~m} / \mathrm{s}^{2}$ occurs in the east-west direction. The response spectra of the event YF (Figure 6) show that the acceleration response peaks between 3 and $6 \mathrm{~Hz}$; at lower frequencies the acceleration response is below $1 \mathrm{~m} / \mathrm{s}^{2}$.

For comparison, the recorded strong motion of the 1999 Chi Chi earthquake, with PGAs exceeding $7.0 \mathrm{~m} / \mathrm{s}^{2}$ in both horizontal components (Table 2), collapses the remains of the Roman Temple (Figure 9). The response spectra of the Tai earthquake (Figure 6) show acceleration responses at $0.5 \mathrm{~Hz}$ above $5 \mathrm{~m} / \mathrm{s}^{2}$ in the horizontal directions and the peaks at a value above $10 \mathrm{~m} / \mathrm{s}^{2}$.

\section{Discussion and Conclusions}

The investigation of precariously balanced rocks is an established method to determine the vibration history of a site and to arrive at reasonable conclusions about the seismic activity of a region. In this study, we apply the same concept to a precariously balanced archaeological structure: the ruin of the Roman Temple of Kedesh. The temple was surveyed with a $3 \mathrm{D}$ laser-scanner. Based on this survey, a discrete element model was created to study the dynamic behavior of the ruin. In addition to 54 analytic ground motion signals (cycloidal pulse) with frequencies ranging from $0.3 \mathrm{~Hz}$ to $2 \mathrm{~Hz}$ and PGAs from $1 \mathrm{~m} / \mathrm{s}^{2}$ to $9 \mathrm{~m} / \mathrm{s}^{2}$, ground motions from eight earthquake scenarios were applied to the model. Two of these are assumed events in close proximity to the ruin; five of the scenarios resemble historical earthquakes of the region documented through archaeo- and palaeoseismological research; the eighth ground motion is a strong motion record from the 1999 Taiwan Chi Chi earthquake.
Simulations with analytical signals reveal two different failure mechanisms: (1) the wall collapses in the direction of horizontal ground motion during the stopping phase of the cycloidal pulse; (2) the wall is falling due to the high inertial forces in the opposite direction of the ground motion. The performance of a wall depends strongly on the ratio between its height and width (h/w-ratio). As expected, the northern wall with the larger $\mathrm{h} / \mathrm{w}$-ratio is more vulnerable to lower frequencies than the southern (smaller) wall.

It is important to emphasize the conclusion that none of the simulated historic earthquakes toppled the temple remains. The actual ground motion at the Kedesh site might have differed somewhat from our forward model, but if the ground motions would have been significantly stronger than in our model, the ruin would have suffered further damage.

At first sight it might be surprising how stable the remains of the Roman Temple of Kedesh are. However, the h/w-ratio of the two wall sections is small compared to most single shell walls. It is hard to give an exact measure due to the varying width at the base of the walls and the differing height; however, an $\mathrm{h} / \mathrm{w}$-ratio can be estimated to 6.5 and 3.2 for the larger and smaller wall sections, respectively. The larger wall reaches the maximum height of 7.26 $\mathrm{m}$ only at its center (Figures 2, 3, and 4) and with the last complete row of ashlars at a height of about $5 \mathrm{~m}$, the effective $\mathrm{h} / \mathrm{w}$-ratio in the dynamic tests might be as small as 4.5 . As pointed out by Hinzen and Montabert [same issue] the $\mathrm{h} / \mathrm{w}$-ratio of a simple free standing wall is at least as important for its dynamic stability as the geometry of the blocks by which it is formed. Some of the Inca walls described as earthquake resistant had $\mathrm{h} / \mathrm{w}$-ratios below 3 [Tor- 
res 2014]. Therefore, we conclude that the remains of the Kedesh Temple achieve their relative low vulnerability from small $\mathrm{h} / \mathrm{w}$-ratios of both wall sections.

The dynamic response of the original temple building has to be assumed to be substantially different from that of its current remains, and therefore it cannot be postulated with certainty that the earthquake of May 19, 363 C.E. transformed the temple from an intact state directly to its current configuration. In addition to (relatively mild) weathering and erosion over the centuries, recent looting has altered the temple structure, and it can be hypothesized with some confidence that many more human alterations occurred in the preceding 1653 years. On the other hand, it is plausible that the front wall of the temple proved to be its most earthquake resistant part. The double shell nature of the wall, the $\mathrm{h} / \mathrm{w}$-ratio, and its north-south orientation contributed to the temple's survival of the historic earthquakes of the region. Also, the two hypothetical earthquakes in the Hula Valley (HBF and HCF in Table 2) did not topple the temple remains. In conclusion, based on our model, we cannot exclude that such earthquakes have happened during the past one and a half millennia. The comparison with a measured strong ground motion from the 1999 Chi Chi earthquake in Taiwan on the other hand shows that such a strong load exceeds the strength of the temple remains. The probability of toppling of the Kedesh Temple ruin during earthquake ground motion depends on frequency prevailing direction and amplitude. In general, according to the simulations, low frequencies at $1 \mathrm{~Hz}$ with PGAs of $6 \mathrm{~m} / \mathrm{s}^{2}$ and above in EW direction would collapse both sections. So in conclusion, if the ruin came to its current appearance during the destruction of the temple in 363 C.E. a PGA of $6 \mathrm{~m} / \mathrm{s}^{2}$ has probably not been reached at the site during any earthquake in the past 1650 years.

Under the aspect of preservation of cultural heritage, the results from this study are reassuring. Even a reoccurrence of one of the strong historic earthquakes is not as threatening to the Kedesh Temple ruins as it might be to other important archaeological structures in the area.

In this study only one interesting structure from the vicinity of the DSTF was studied. An extension of the suggested approach to other (more or less) precariously balanced archaeological structures in the area can help to gain additional information about past seismicity and the nature of ground motions in this interesting region. One of the chief ad- vantages of this approach is that no reconstruction of an archaeological structure is required. This type of process therefore reduces uncertainties in the archaeoseismological modeling process and, similar to the case of precariously balanced rocks, ground motion levels can be estimated which have not been exceeded during certain time periods.

\section{Data and Resources}

The initial DEM model was created in 3DEC 5.0, Itasca Consulting Group. 3DEC Universal Distinct Element Code. Minneapolis, USA, 1998. With Blender (v. 2.77a), a 3D modelling and rendering package, Blender Online Community, Blender Foundation Blender Institute, Amsterdam, the initial model was transformed in a format readable by UNITY (v. 5.3.5f1), Unity Technologies Ltd. Photo editing was done with Gimp 2.8 (http: / / www.gimp.org/, last accessed April 2015).

Acknowledgements. We thank Elisa Kagan for the support during the field work. We thank Itasca for providing the 3DEC code and Lothar te Kamp for his support during model development. The work was in parts financed by the German-Israeli Foundation for Scientific Research and Development for the support (GIF 1165-161.8/2011).

\section{References}

Akyuz, H. S., E. Altunel, V. Karabacak, C. C. Yalciner (2006). Historical erathquake activity of the northern part of the Dead Sea Fault Zone, southern Turkey, Tectonophysics, 426, 281-293.

Altunel, E., M. Meghraoui, V. Karabacak, S. H. Akyuz, M. Ferry, C. C. Yalciner, M. Munschy (2009). Archaeological sites (Tell and Road) offset by Dead Sea Fault in the Amik Basin, Southern Turkey, Geophys. J. Int., 179, 1313-1329.

Ambraseys, N. N., M. Barazangi (1989). The 1759 Earthquake in the Bekaa Valles: Implications for Earthquake Hazard Assessment in the Eastern Mediterranean Region, J. Geophys. Res., 94, 4007-4013.

Ambraseys, N. N. (2006). Comparison of frequency of occurrence of earthquakes with slip rates from long-term seismicity data: the cases of Gulf of Corinth, Sea of Marmara and Dead Sea Fault Zone, Geophys. J. Int., 165, 516-526.

Amit, R., J. B. J. Harrison, Y. Enzel, N. Porat (1996). Soils as a tool for estimating ages of Quaternary fault scarps in a hyperarid environment - The southern Arava Valley, the Dead Sea rift, Israel, Catena, 28, 21-45. 
Amit, R. E. Zilberman, N. Porat, Y. Enzel (1999). Relief inversion in the Avrona Playa as evidence of large-magnitude historical earthquakes, southern Arava Valley, Dead Sea rift, Quat. Res., 52, 76-91.

Amit, R. E. Zilberman, Y. Enzel, N. Porat (2002). Paleoseismic evidence for time dependency of seismic response on a fault system in the southern Arava Valley, Dead Sea rift, Israel. Geol. Soc. Am. Bull., 114, 192-206.

Anooshehpoor, A., J. N. Brune, Y. Zeng (2004). Methodology of Obtaining Constraints on Ground Motion from Precariously Balanced Rocks, Bull. Seism. Soc. Am., 94, 285-303.

Baer, G., D. Sandwell, S. Williams, Y. Bock (1999). Coseismic deformation associated with the November 1995, $M_{w}=7.1$ Nuweiba earthquake, Gulf of Elat (Aqaba), detected by synthetic aperture radar interferometry, J. Geophy. Res., 104, 25221-25232.

Bartov,Y. , G. Steinitz, M. Eyal, Y. Eyal (1980). Sinistral movement along the Gulf of Aqaba - Its age and relation to the opening of the Red Sea, Nature, 285, 220-221.

Ben-Menahman, A. (1991). Four thousand years of seismicity along the Dead Sea Rift, J. Geophys. Res., 96, 20195-20216.

Brune, J. N. (1996). Precariously balanced rocks and ground motion maps for southern California, Bull. Seism. Soc. Am., 86, 43-54.

Chorowicz, J., D. Dhont, O. Ammar, M. Rukieh, A. Bilal (2005). Tectonics of the Pliocene Homs, basalts (Syria) and implications for the Dead Sea Fault Zone activity, J. Geo. Soc., 162 , 259-271.

Conder, C. R. and H. H. Kitchner (1882). The Survey of Western Palestine, II Samaria. London: Palestine Exploration Fund, pp. 3760.

Cundall, P. A. (1988). Formulation of Three-dimensional Distinct Element Model - Part I. A Scheme to Detect and Represent Contact in a System Composed of Many Polyhedral Blocks, Int. J. Rock Mech. Min. Sci. \& Geomech. Abstr., 25, 107-116.

Cundall, P. A. and R. D. Hart (1992). Numerical Modelling of Discontinua, Engineering Computations, 9, 101-113.

Daëron, M., L. Benedetti, P. Tapponier, A. Sursock, R. C. Finkel (2004). Constraints on the post 25$\mathrm{ka}$ slip rate of the Yammouneh fault (Lebanon) using in situ cosmogenic $36 \mathrm{Cl}$ dating of offset limestone-clast fans, Earth Planet Sci. Lett., 227, 105-119.

Daëron, M., Y. Klinger, P. Tapponier, A. Elias, E. Jacques, A. Sursock (2005). Sources of the large AD
1202 and 1759 Near East earthquakes, Geology, 33, 529-532.

Daëron, M., Y. Klinger, P. Tapponier, A. Elias, E. Jacques, A. Sursock (2007). 12,000-year-long record of 10 to 13 paleoearthquakes on the Yammouneh Fault, Levant Fault system, Lebanon, Bull. Seism. Soc. Am., 97, 749-771.

Ellenblum, R., S. Marco, A. Agnon, T. Rockwell, A. Boas (1998). Crusader castle torn apart by earthquake at dawn, 20 May 1202, Geology, 4, 303-306.

Ellenblum, R., S. Marco, R. Kool, U. Davidovitch, R. Porat, A. Agnon (2015). Archaeological record of earthquake ruptures in Tell Ateret, the Dead Sea Fault, Tectonics, 34, 2105-2117.

Elias, A., P. Tapponnier, S.C. Singh, G.C.P. King, A. Briais, M. Daëron, H. Carton, A. Sursock, E. Jacques, R. Jomaa, Y. Klinger (2007). Active thrusting offshore Mount Lebanon: source of the tsunamigenic A.D. 551 Beirut-Tripoli earthquake, Geology, 35, 755-758.

Enzel, Y., G. Kadan, Y. Eyal (2000). Holocene Earthquakes inferred from a fan-delta sequence in the Dead Sea graben, Quat. Res., 53, 34-48.

Fenner, F. 1905. In Obergalilaa. PJb 1:99-IIO.

Ferry, M., M. Meghraoui, N. Abou Karaki, M. Al-Taj, H. Amoush, M. Barjous (2007). A 48-kyr-long slip rate history for the Jordan Valley segment of the Dead Sea Fault, Earth Planet Sci. Lett., 260, 394-406.

Ferry, M., M. Meghraoui, N. Abou Karaki, M. Al-Taj, M. Khalil L (2011). Episodic behavior of the Jordan Valley section of the Dead Sea fault inferred from a 14-ka-long integrated catalog of large earthquakes, Bull. Seism. Soc. Am., 101, 39-67.

Fischer, M., A. Ovadiah, I. Roll (1984). The Roman Temple at Kedesh, Upper Galilee, Tel Aviv 11, 146-172.

Fleischer, C., K.-G. Hinzen, S. Schreiber (2010). Laserscanning eines römischen Brunnens in der Archäologsichen Zone Köln, Allgemeine Vermessungs Nachrichten 5/2010, 176-181.

Freund, R. (1965). A model of the structural development of Israel and adjacent areas since Upper Cretaceous times, Geol. Mag., 102, 189-205.

Freund, R., I. Zak, Z. Garfunkel (1968). Age and rate of the sinistral movement along the Dead Sea Rift, Nature, 220, 253-255.

Galadini, F., K.-G. Hinzen, S. Stiros (2006). Archaeoseismology: Methodological issues and procedure, Journal of Seismology, 10, 395-414.

Galli, P. (1999). Active tectonics along the Wadi Araba-Jordan Valley transform fault, J. Geophys. Res., 104, 2777-2796. 
Garfunkel, Z. (1981). Internal structure of the Dead Sea leaky transform (rift) in relation to plate kinematics, Tectonophysics, 80, 81-108.

Gomez, F., M. Meghraoui, A. N. Darkal, R. Sbeinati, R. Darawcheh, C. Tabet, M. Khawlie, M. Charabe, K. Khair, M. Barazangi (2001). Coseismic displacements along the Serghaya fault: an active branch of the Dead Sea Fault system in Syria and Lebanon, J. Geol. Soc., 158, 405-408.

Gomez, F. M. Meghraoui, A. N. Darkal, F. Hijazi, M. Mouty, Y. Suleiman, R. Sbeinati, R. Darawcheh, R. Aal-Ghazzi, M. Barazingi (2003). Holocene fautling and earthquake recurrence along the Serghaya branch of the Dead Sea fault system in Syria and Lebanon, J. Geol. Soc., 153, 658-674.

Gomez, F., G. Karam, M. Khawlie, S. McClusky, P. Vernant, R. Reilinger, R. Jaafar, C. Tabet, K. Khair, M. Barazangi (2007). Global Positioning System measurements of strein accumulation and slip transfer through the restraining bend along the Dead Sea fault system in Lebanon, Geophys. J. Int., 168, 1021-1028.

Hart, R. D. and P. A. Cundall (1988). Formulation of a Three-dimensional Distinct Element Model - Part II. Mechanical Calculations for Motion and Interaction of a System Composed of Many Polyhedral Blocks, Int. J. Rock Mech. Min. Sci. \& Geomech. Abstr., 25 , 117-125.

Haynes, J. M., T. M. Niemi, M. Atallah (2006). Evidence for ground-rupturing earthquakes on the northern Wadi Araba fault at the archaeological site of Qasar Tilah, Dead Sea Transform fault system, Jodran, Journal of Seismology, 10, 415-430.

Hinzen, K.-G. (2005). The Use of Engineering Seismological Models to Interpret Archaeoseismological Findings in Tolbiacum, Germany: A Case Study, Bull. Seism. Soc. Am., 95, 521-539.

Hinzen, K.-G., C. Fleischer, S. K. Reamer, S. Schreiber, S. Schütte, B. Yerli (2009a). Quantitative Methods in Archaeoseismology. In: R. Pérez-López, C. Grützner, J. Lario, K. Reicherter, P.G. Silva (edts), 1st INQUA-IGCP-567 International Workshop on Earthquake Archaeology and Palaeseismology, Baelo Claudia, Spain, 50-51.

Hinzen, K.-G. (2009 b). Sensitivity of earthquake-toppled columns to small change in ground motion and geometry, Israel J. Earth Sci., 58, 309-326.

Hinzen, K.-G. and R. Kovalev (2010). Hiller's Seismoscope, Seismological Research Letters, 81, 804-810.

Hinzen, K.-G., S. Schreiber, C. Fleischer, S. K. Reamer, I. Wiosna (2012). Archaeoseismic study of damage in Roman and Medieval structures in the center of Co- logne, Germany, Journal of Seismology, 17, 339-424.

Hinzen, K.-G., H. Kehmeier, S. Schreiber (2013). Quantitative Archaeoseismological Study of a Roman Mausoleum in Pinara (Turkey)-Testing Seismogenic and Rockfall Damage Scenarios, Bull. Seism. Soc. Am., 103, 1008-1021.

Hinzen, K.-G. and A. Montabert (this issue). Rectangular Blocks vs Polygonal Walls in Archaeoseismology, Annals of Geophysics, this volume.

Hofstetter, A., C. Dorbath, L. Dorbath (2014). Instrumental data on the seismic activity along the Dead Sea Transform. In: Garfunkel, Z. , Ben-Avraham Z, Kagan E (eds) The Dead Sea Transform. Springer, Dordrecht, 263-278.

Housner, G. W. (1963). The behavior of inverted pendulum structures during earthquakes, Bull. Seism. Soc. Am., 53, 403-417.

Karabacak, V., E. Altunel, M. Meghraoui, H. Akyüz (2010). Field evidences from northern Dead Sea Fault Zone (South Turkey): new findings for the initiation age and slip rate, Tectonophysics, 141, 172-182.

Klinger, Y., L. Rivera, H. Haessler, J.C. Maurin (1999). Active Faulting in the Gulf of Aqaba: New Knowledge from the $M_{w} 7.3$ Earthquake of 22 November 1995, Bull. Seism. Soc. Am., 89, 4, 1025-1036.

Klinger, Y., J. P. Avouac, N. Abou Karaki, L. Dorbath, D. Bourles (2000a). Slip rate on the Dead Sea Transform fault in northern Araba Valley (Jordan), Geophys. J. Int., 142, 755-768.

Klinger, Y., J. P. Avouac, L. Dorbath, N. Abou-Karaki, N. Tisnerat (2000b). Seismic behavior of the Dead Sea Fault along Araba Valley, Jordan, Geophys. J. Int., 142, 769-782.

Le Beon, M., Y. Klinger, A. Q. Amrat, A. Agnon, L. Dorbath, G. Baer, J. C. Ruegg, O. Charade, O. Mayyas (2008). Slip rate and locking depth from GPS profiles across the southern Dead Sea Transform, J. Geophys. Res. Solid Earth, 113, B11403, pp 19.

Le Beon, M., Y. Klinger, M. Al-Qaryouti, A. S. Meriaux, R. C. Finkel, A. Elias, O. Mayyas, F. J. Ryerson, P. Tapponnier (2010). Early Holocene and Late Pleistocene slip rates of the southern Dead Sea Fault determined from Be-10 cosmogenic dating of offset alluvial deposits, J. Geophys. Res. Solid Earth, 115, B11414, pp 24.

Le Beon, M., Y. Klinger, A. S. Meriaux, M. Al-Qaryouti, R. C. Finkel, O. Mayyas, P. Tapponnier (2012). Quaternary morphotectonic mapping of the Wadi Araba and implications for the tectonic activity of the southern Dead Sea fault, Tectonics, 21, TC5003, pp 25. 
Makovsky, Y., A. Wunch, R. Ariely, Y. Shaked, A. Rivilin, A. Shemesh, Z. Ben Avraham, A. Agnon (2008). Quaternary transform kinematics constrained by sequence stratigraphy and submerged coastline features: the Gulf of Aqaba, Earth Planet. Sci. Lett., 271, 109-122.

Marco, S. and A. Agnon (1995). Prehistoric earthquake deformations near Masada, Dead Sea graben, Geology, 23, 695-698.

Marco, S., A. Agnon, R. Ellenblum, A. Eidelman, U. Basson, A. Boas (1997). 817-Year-Old Walls Offset Sinistral $2.1 \mathrm{~m}$ by the Dead Sea Transform, Israel, Journal Geodynamics, 24, 11-20.

Marco, S., M. Hartal, N. Hazan, L. Lec, M. Stein (2003). Archaeology, history, and geology of the A.D. 749 earthquake, Dead Sea Transform, Geology, 31, 665-668.

Marco, S., T. K. Rockwell, A. Agnon, A. Heimann, U. Frieslander (2005a). Late Holocene slip of the Dead Sea Transform revealed in 3D palaeoseismic trenches on the Jordan Gorge Fault, Earth Planet. Sci. Lett., 234, 189-205.

Marco, S. and A. Agnon (2005b). High-resolution stratigraphy reveals repeated earthquake faulting in the Masada Fault Zone, Dead Sea Transform, Tectonophysics, 408, 101-112.

Marco, S. and Y. Klinger (2014). Review of On-Fault Palaeseismic Studies Along the Dead Sea Fault. In: Garfunkel Z, Ben-Avraham Z, Kagan E (eds) The Dead Sea Transform. Springer, Dordrecht, 183-205.

Meghraoui, M., F. Gomez, R. Sbeinati, J. Van der Woerd, M. Mouty, A. N. Darkal, Y. Radwan, I. Layyous, H. A. Najjar, R. Darawcheh, F. Hijazi, R. Al-Ghazzi, M. Barazangi (2003). Evidence for 830 years of seismic quiescence from palaeoseismlogy, aechaeoseismology and historical seismicity along the Dead Sea faul in Syria, Earth Planet Sci. Lett., 210, 35-52.

Migowski, C., A. Agnon, R. Bookman, J. F. W. Negendank, M. Stein (2004). Recurrence pattern of Holocene earthquakes along the Dead Sea Transform revealed by varve-counting and radiocarbon dating of lacustrine sediments, Earth Planet. Sci. Lett., 222, 301-314.

Nemer, T. and M. Meghraoui (2006). Evidence of coseismic ruptures along the Roum fault (Lebanon): a possible source for the AD 1837 earthquake, J. Struct. Geol., 28, 1483-1495.

Nemer, T., M. Meghraoui, K. Khair (2008). The Rachaya-Serghaya fault system (Lebanon): evidence of coseismic ruptures, and the AD 1759 earthquake sequence, J. Geophys. Res., 113, B05312.

Niemi, T. M., H. Zhang, M. Atallah, J. B. J. Harrison
(2001). Late Pleistocene and Holocene slip rate of the Northern Wadi Araba fault, Dead Sea Transform, Jordan, Journal of Seismology, 5, 449-474.

Psycharis, I. N., J. V. Lemos, D. Y. Papastamatiou, C. Zambas, C. Papatonopoulus (2003). Numerical study of the seismic behavior of a part of the Pathenon Pronaos, Earthquake Engineering and Structural Dynamics, 32, 2063-2084.

Quennell, A. M. (1956). Tectonics of the Dead Sea rift. In: Asociacion de Servicios Geologicos Africanos, Congreso Geologico Internactinal, 20th session, Mexico, 385-405.

Richter, C.F (1958). Elementary Seismology, Freeman, San Francisco, Calif., 578 pp.

Reches, Z. and D. F. Hoexter (1981). Holocene seismic and tectonic activity in the Dead Sea area, Tectonophysics, 80, 235-254.

Sadeh, M., Y. Hamiel, A. Ziv, Y. Bock, P. Fang, S. Wdowinski, S. (2012). Crustal deformation along the Dead Sea Transform and the Carmel Fault inferred from 12 years of GPS measurements, J. Geophy. Res. Solid Earth, 117, B8, B08410.

Shamir, G., G. Baer, A. Hofstetter (2003). Three-dimensional elastic earthquake modelling based on integrated seismological and InSAR data: the $\mathrm{M}_{\mathrm{w}}=7.2$ Nuweiba earthquake, gulf of Elat/Aqaba 1995 November, Geophys. J. Int., 154, 731-744.

Shapira, A., R. Avni, A. Nur (1993). A new estimate for the epicenter of the Jericho earthquake of 11 July 1927, Israel Journal of Earth Sciences, 42, 93-96.

Schreiber, S., K.-G. Hinzen, C. Fleischer, S. Schütte (2012). Excavation-parallel laser scanning of a medieval cesspit in the archaeological zone Cologne, Germany. ACM J. Comput. Cult. Herit., 5, 3, Article 12 (October 2012), 22 pp.

The Geophysical Institute of Israel (GII) (2013). Seismological Bulletin Earthquakes in and around Israel During 2009. Report GII No 030/715/13January2013, 13-14.

Thomas, R., T. M. Niemi, S. T. Parker (2007). Structural damage from earthquakes in the second-ninth centuries at the archaeological site of Aila in Aqaba, Jordan, Bull. Am. Sch. Orient. Res., 346, 59-77.

Torres, H. E. (2014). Builders in pre-Hispanic Peruvian Andes: analytical approaches to knowledge their seismic resistance, in 9th International Conference on Structural Analysis of Historical Constructions F. Peña and M. Chávez (eds.), Mexico City, www. hms.civil.uminho.pt/sahc/2014/ topic08-fullpaper034.pdf, last accessed June 2016.

Wang, R. (1999). A simple orthonormalization meth- 
od for stable and efficient computation of Green's functions, Bull. Seism. Soc. Am., 89, 733-741.

Wechsler, N., T. K. Rockwell, Y. Klinger, P. Štěpančíková, M. Kanari, S. Marco, A. Agnon (2014). A Palaeoseismic Record of Earthquakes for the Dead Sea Transform Fault between the First and Seventh Centuries C.E.: Nonperiodic Behavior of a Plate Boundary Fault, Bull. Seism. Soc. Am., 104, 1329-1347.

Wells, D. L. and K. J. Coppersmith (1994). New empirical relationships among magnitude, rupture length, rupture width, rupture area, and surface displacement, Bull. Seism. Soc. Am., 84, 974-1002.

Wetzler, N. and I. Kurzon (2016). The Earthquake Activity of Israel: Revisiting 30 Years of Local and Regional Seismic Records along the Dead Sea Transform, Seismological Research Letters, 87, 47-58.

Wdowinski, S., Y. Bock, G. Baer, L. Prawirodirdjo, N. Bechor, S. Naaman, R. Knafo, Y. Forrai, and Y. Melzer (2004). GPS measurements of current crustal movements along the Dead Sea Fault, J. of Geophys. Res., 109, B05403.

Wilson, J. T. (1965). A new class of faults and their bearing on continental drift, Nature, 207, 343-347.

Zang J. and N. Makris (2001). Rocking response of free-standing blocks under cycloidal pulses, J. Eng. Mechanics, 127, 473-483.

Zilbermann, E., R. Amit, A. Heimann, N. Porat (2000). Changes in Holocene paleoseismic activity in the Hula pull-apart basin, Dead Sea rift, northern Israel, Tectonophysics, 321, 237-252.

Zilbermann, E., R. Amit, N. Porat, Y. Enzel, U. Avner (2005). Surface ruptures induced by the devastating $1068 \mathrm{AD}$ earthquake in the southern Arava valley, Dead Sea rift, Israel, Tectonophysics, 408, 79-99.

Zohar, M. and S. Marco (2012). Re-estimating the epicenter of the 1927 Jericho earthquake using spatial distribution of intensity data, Journal of Applied Geophysics, 82, 19-29.

\footnotetext{
${ }^{*}$ Corresponding author: Gregor Schweppe

Erdbebenstation Bensberg, Universität zu Köln; Bergisch Gladbach, Germany email: gregor.schweppe@uni-koeln.de.

2017 by Istituto Nazionale di Geofisica e Vulcanologia.

All rights reserved
} 